\title{
Analysis of the Mawar Gentong Surakarta Batik Motif in A Charles Sanders Peirce's Semiotic Study
}

\author{
Alifia Zahra Khoirunnisa ${ }^{1}$, I Ketut Sunarya ${ }^{2}$ \\ ${ }^{1}$ Arts Education Graduate Program, Yogyakarta State University, Depok 55281, Yogyakarta, Indonesia \\ ${ }^{2}$ Department of Fine Arts Education, Yogyakarta State University, Depok 55281, Yogyakarta, Indonesia
}

\begin{abstract}
Batik is a work of art that contains a depiction of meaning based on the motifs that exist on the batik itself, describing the meaning can be analyzed from the parts of existing motifs, and make a story or expression of taste. Batik motif acts as a basis or principle for drawing patterns, which is the midpoint of the design. One of the batik motifs that became the icon of CV. Batik Morinda is Mawar Gentong. This study aims to describe the creation and meaning of Mawar Gentong batik motifs made by Muhammad Sahid in CV. Batik Morinda. It is qualitative research with Peirce's theory of semiotic approach in the form of three main elements, namely representant, object, and interpretant. Research data were collected through observation, interview, and documentation and analyzed by data reduction, data presentation, and conclusion. The results show that (1) the form of the Mawar Gentong batik motif was inspired by the round rose buds and earthen pots combined and refined into the Mawar Gentong motif; and (2) the meaning of the motif itself is that the shape of the rose has a beautiful aesthetic meaning as a form of love and friendship, while gentong is an interpretation of a clay container to hold water which means as a symbol of patience and sincerity. The overall meaning of Mawar gentong batik motif is to sincerely knit affection or friendship to fellow human beings so that they will be able to spread goodness as fragrant as that of roses.
\end{abstract}

Keywords: Batik, Mawar, Gentong, Semiotics, Peirce

\section{INTRODUCTION}

Batik is the monumental cultural heritage work of art of the Indonesian people. As a monumental piece of art, batik is one of the crafts with incredibly high value art and craftsmanship that becomes a significant part of the Indonesian culture [1]. Batik was officially recognized by UNESCO by being included in the Representative List of the Intangible Cultural Heritage of Humanity in the Fourth Session of the Intergovernmental Committee on NonCultural Heritage in Abu Dhabi. Throughout the years, batik has remained popular among all levels of society in Indonesia and regarded as one of the official dress codes in Indonesia.

The attractiveness of batik is influenced by many factors, including the motif, pattern, and colour. For instance, the motif and colour of batik produced in the coastal regions, such as Lasem, tend to have some characteristics of the Chinese culture due to the strong influence of Chinese descendants in the regions. This is proof that batik is an important part of the world-renowned noble culture of Indonesia.

According to the National Encyclopaedia of Indonesia [2], batik is a traditional Indonesian art of decorating a piece of fabric and other materials by creating motifs using a special type of wax-based dye. Batik also refers to the piece of white cloth that is drawn on, dyed, and processed in a traditional fashion. The term batik according to Wulandari [3] is the action of connecting the dots into a certain pattern or drawing on a wide piece of fabric. The term is also associated with the dots of wax on a white piece of cloth, which is appropriate with the word's original meaning in Javanese, in which it is spelled using the character tha (as in bathik), meaning that it represents a series of dots which take the shape of certain pattern or drawing.

The creation of Batik motif has a long unique history that is often accompanied by interesting stories. Batik motif is the basis or essence of a drawing pattern that serves as the centre or main point of the design and creates meaning from the signs or symbols to be unravelled [4]. Motif is the smallest component of a drawing or basis of a pattern. According to Rasjoyo, motif serves as the drawing basis or template that ultimately creates the final result in a gradual manner [5]. 
One of the most interesting new batik motifs to study is the mawar gentong, the icon or signature motif of Batik Morinda production house. According to Khoirunisa, in 2005, the barrel-shaped rose motif was introduced to the public in an exhibition, which then convinced Muhammad Sahid, the founder and head of the Batik Morinda, to make the mawar gentong batik motif as the signature icon motif of his production house [6]. Batik Morinda is one of the thriving batik craft businesses in the Karanganyar area, Surakarta, which was founded by a businessman and creator of the mawar gentong batik motif, Muhammad Sahid. The mawar gentong batik motif was created based on his love of various plants, especially roses, which inspired him to create the very interesting and unique motif. Due to its uniqueness, an in-depth study was needed to reveal the concepts and meanings in the motif using Peirce's theory as the basis of analysis.

According to Peirce, human life cannot be separated from signs, and signs always have and contain meaning. Meaning communicates a message to the appreciator. Peirce also points out that the central point of his semiotic study is the relation trichotomy between the sign (representant) and the object through an interpretant as another equivalent sign in a person's mind [interpreter]. Hence, meaning interpretation by the sign user is achieved when the representative is linked to the object. Meanwhile, the object referred to by the sign is a concept known by the sign user as "reality" or anything considered to exist [7][8].

Semiotics is a study or method which analyses the signs in the context of scenario, text, and scenes in a movie into something understandable. The word semiotic is originated from the Greek word semeion which means sign, or seme which means the sign interpreter. Semiotics is rooted in classical and scholastic studies on the art of logic, rhetoric, and ethics. Referring to Peirce's theory, the signs in the images or visual objects can be perceived from the type of signs classified in semiotics [9]. Peirce mentions three elements of semiotics, namely representant, object, and interpretant, in which the signs can be manifested as icons, indexes, and symbols.

Based on these notions, this study investigates the following aspects.

- The concept of creation of mawar gentong batik motif by Muhammad Sahid

- Representant from the sign meaning in the mawar gentong batik motif based on Charles Sanders Peirce' semiotic analysis

\section{RESEARCH METHOD}

This study was developed from a previous study entitled Analysis of Bunga Mawar Gentong Batik Shawl Code (SH.MG04_2008) by Muhammad Sahid (Khoirunisa, 2017). This was a qualitative research using a semiotic approach, focusing on the analysis of mawar gentong batik motif (code (SH.MG04_2008)). This study consisted of four stages. The first stage was gathering various sources related to the research topic on batik. The second stage was conducting an analysis of the mawar gentong batik motif (SH.MG04_2008) by linking the meaning of Javanese cultural symbols to further deepen the context of the symbol on the mawar gentong batik motif. The third stage of the semiotic approach was examining the visual signs contained in the mawar gentong batik motif (SH.MG04_2008). Finally, in the fourth stage disclosure of historical meaning with a structural approach was done to obtain a correct understanding of the meaning and how it appears. To explain the meaning of the sign relationship, the interpretation model $\mathrm{X}=\mathrm{Y}$ was used, in which $\mathrm{X}$ referred to the object, and $\mathrm{Y}$ was the meaning with all its dimensions (personal, social and historical).

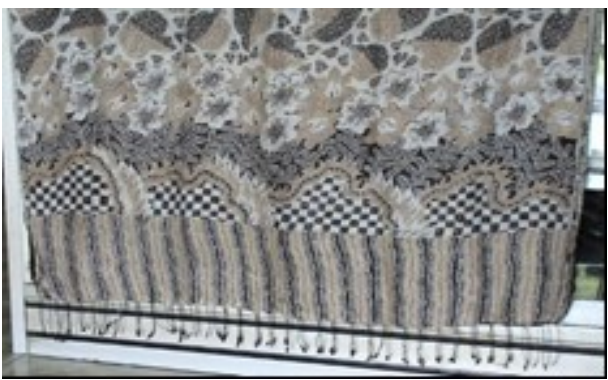

Figure 1 Mawar Gentong Batik Motif (SH.MG04_2008)

In order to analyse the visual object of the mawar gentong batik motif, the researcher used the triadic semiotic approach with three basic elements from Charles Sander Peirce, consisting of representation (sign), object (society's cognitive view), and interpretation. According to Peirce, human life cannot be separated from signs, and signs always have and contain meaning. Meaning communicates a message to the appreciator. Peirce also points out that the central point of his semiotic study is the relation trichotomy between the sign (representant) and the object through an interpretant as another equivalent sign in a person's mind (interpreter). Hence, meaning interpretation by the sign user is obtained when the representative is linked to the object. Meanwhile, the object referred to by the sign is a concept known by the sign user as "reality" or anything considered to exist [7][8] The triadic (three basic elements) semiotic scheme by C.S. Peirce can be seen below. 


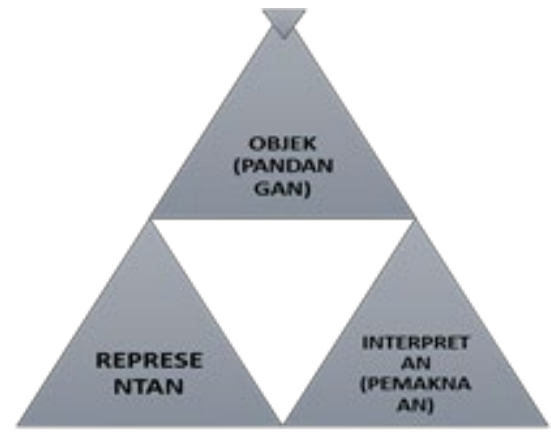

Scheme 1 Peirce's Three Semiotic Elements

\section{RESULTS AND DISCUSSION}

Motif is a variety of styles with different characteristics applied on the batik cloth. The motif in batik cloth can also be defined as the main pattern which characterizes and determines the type of batik style [10]. The development of increasingly evolving batik motifs is ultimately a result of the influence of the Industrial Revolution 4.0. This development allows artists and craftspeople to continue developing their ideas in producing new creations.

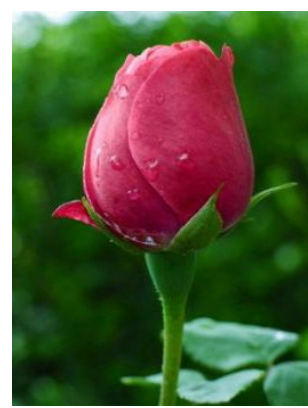

Figure 2 A Rosebud

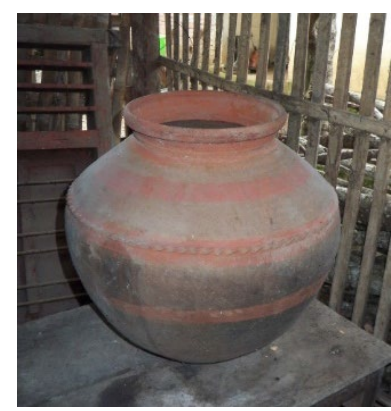

Figure 3 A Gentong (clay barrel)
The combination of the shapes of the rosebud and the gentong or clay barrel generates a new kind of batik motif shape by Muhammad Sahid. The rosebud shape with the leaf surrounding it is a distinct feature of Batik Morinda. Many consider the shape to be unique dan luxurious. This motif is combined with other spontaneous motifs. The craftsperson usually adds details to give additional aesthetic values in the batik motif. This results in various combinations of shapes and forms of the mawar gentong batik motif with each of their distinct features.

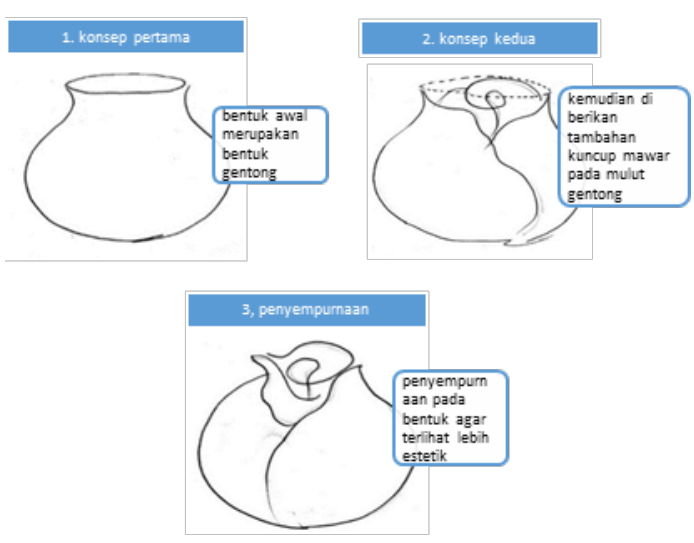

Figure 4 Creation Concept

1. First stage: the outline of the barrel as the initial shape

2. Second stage: addition of the rosebud at the top part of the barrel stage

3. Third stage: refined version of the shape to produce the finished result

Figure 3 depicts the creation concept of the mawar gentong motif. There are three stages in the creation process. The first stage consists of making the initial outline of the clay barrel (gentong) in a round shape with no support at the bottom (feet). In the second stage, the flower element is added at the top part of the round shape in the form of the rosebud details with the body of the barrel, resulting in a new shape. Finally, in the third stage, the new motif is refined by adding other aesthetic elements and details to produce the final result of the new creation. 
The following table depicts Peirce's three elements of semiotics in relation to the batik motif:

Table 1. Description of Peirce's three semiotic elements

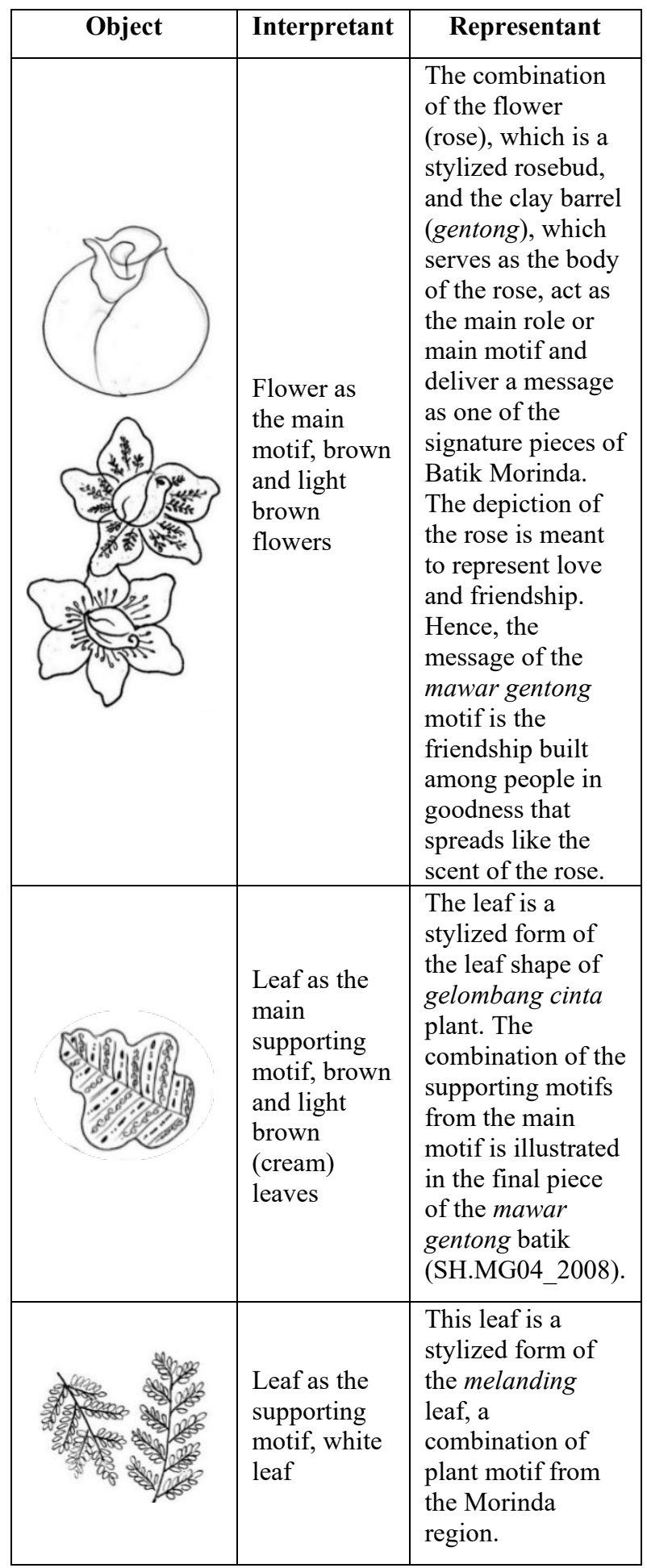

Muhammad Said's batik motif implies hope and inspiration as the message for the customers in the creation of the mawar gentong batik motif. This was the first batik motif produced on the fabric. As the heir of Batik Morinda Eka Rahmawati agrees that the message in the mawar gentong motif is a profound one as it serves to celebrate love and friendship. As a symbol, roses are known to represent love and friendship.

Most people, including art observers, consider flowers as a symbol of expression of feelings based on the type and colour of the flower. Essentially, humans need to express what they feel in life. Rose is one of the mediums that delivers a message in a piece of art. The rosebud shape in the motif is the stylization of the flower that is combined with the round barrel shape of the gentong, ultimately creating an elegant and classic shape. The two modest classic colours are what makes the batik motif even more beautiful.

In contrast to Muhammad Sahid's initial thought on the lack of versatility of the motif, an interview with Landra, one of the loyal customers of Batik Morinda, reports that the mawar gentong motif can in fact easily serve as a gift due to its combination of classic motif and colour which represents gentleness and elegance on the wearer.

Visually, the batik motif is a rosebud shape with a round barrel-shaped body. According to Rukmana [11] roses can represent many things, including as a symbol of love, beauty, respect, youth, joy, as well as condolence. On the other hand, based on the Javanese philosophy, it is a part of an important set-up for Javanese traditional ceremonies called Mawi-Arsa, which means "with intent or will." This means that in Javanese culture, the rose brings a particular meaning of how each intention must be founded on sincerity. Furthermore, the clay barrel or gentong is defined as wadhah banyu gedhe saember genuk (digawe saka lemah lempung dicithak banjur diobong), or "a large water container (made of clay that is moulded and fired)." The meaning of the word gentong is directly related to the concept of containing water. In this sense, it is typically the clean water taken from the well or spring which symbolizes the water of life.

According to Hendry Suprapto (based on an interview on August 3, 2019), the mawar gentong motif represents the building of friendship among people in goodness; it is hoped that the good deeds are sincere like the scent of the rose. The mawar gentong (SH.MG04_2008) batik has supporting motifs in which the aesthetic elements are inspired from the surrounding. The result of the research on the mawar gentong (SH.MG04_2008) batik motif by Muhammad Sahid shows that the motif is unique in terms of the production planning concept. A previous study points out that this motif is an exclusive limited type of batik. In the production stage, the Batik Morinda company is committed to not produce the same pattern twice. This means that each of the batik craftsperson (pencorek) must rely on his or her own creativity. The following are the components of the mawar gentong (SH.MG04_2008) motif: 
Table 2. Components of the Mawar Gentong Batik (SH.MG04_2008)

\begin{tabular}{|l|l|l|}
\hline No. & \multicolumn{1}{c|}{ Description } \\
\hline 1. & $\begin{array}{l}\text { This is the shape of the } \\
\text { mawar gentong batik } \\
\text { motif (SH.MG04_2008). } \\
\text { It shapes like a rosebud } \\
\text { with a body of a barrel } \\
\text { surrounded with leaves. }\end{array}$ \\
\hline
\end{tabular}

In the development of the motif, the concept of the combination is inspired from the surrounding environment of Muhammad Sahid in Karanganyar. An interview with Sumami reported that his gardening hobby has inspired him for creating this motif. This particular motif is dominated by plants. The combination does not have a significant meaning, and only serves to add visual aesthetic values from the shapes of the plants.

\section{CONCLUSION}

M The concept of creating the mawar gentong batik motif is the result of stylization, experience, and observation of the surrounding by Muhammad Sahid. The shape of the motif on the mawar gentong batik shawl (SH.MG04_2008) is inspired by a combination of rosebud and gentong, a traditional Javanese clay barrel. The rosebud motif that is combined with the round (plump) shape of the body of the barrel makes a one of a kind beautiful batik motif.

Based on Peirce's semiotic analysis of the three elements, which includes the object, representant, and interpretant, this study finds that the mawar gentong batik motif (SH.MG04_2008) represents love and affection. In Javanese philosophy, the motif can be interpreted as a sincere feeling. In this sense, the clay barrel, which originally functions as a water container, is used to support the rose on top. Therefore, the barrel becomes a container of affection or love. Moreover, in Javanese philosophy, gentong may also serve as wadhah banyu, which means "the container of water that becomes the water of life." In conclusion, the mawar gentong motif is a symbol of sincere love and affection toward others, in which the scent evokes love and compassion toward all beings 


\section{REFERENCES}

[1] Prasetyo, Anindito. Batik: karya agung warisan budaya dunia [Batik: a masterpiece of Indonesian cultural heritage]. Pura Pustaka, 2010. p. 4.

[2] Indonesia. 2004. Kamus Ensiklopedi Nasional Indonesia: Jilid Keempat [Indonesian National Encyclopaedia Dictionary]. Bekasi: PT. Delta Pamungkas. p. 206.

[3] Wulandari, Ari, and Martha Nina K. Batik Nusantara. Andi, 2011. p. 4.

[4] Wulandari, Ari, and Martha Nina K. Batik Nusantara. Andi, 2011. p. 113.

[5] Rasjoyo. 2008. Mengenal Batik Tradisional [Get to Know Traditional Batik]. Jakarta: Azka Press. p. 15.

[6] Khoirunisa, Alifia Zahra. "Analisis Selendang Batik Mawar Gentong Kode SH MG04_2008 Karya Muhammad Sahid [The Analysis of Batik Mawar Gentong Code SH. MG04_2008 made by Muhammad Sahid] Pend. Seni Kerajinan-S1 (eCraft) 6.6 (2017): 644-655. URL:

http://journal.student.uny.ac.id/ojs/index.php/ecraf t/article/view/8730

[7] Budiman, Kris. Semiotika visual: konsep, isu, dan problem ikonisitas [Visual semiotics: concepts, issues and problems of iconicity]. Jalasutra, 2011. pp. 49-53.

[8] Hoed, Benny H. Semiotik dan dinamika sosial budaya: ferdinand de saussure, roland barthes, julia kristeva, jacques derrida, charles sanders peirce, marcel danesi \& paul perron, dll [Semiotic and socio-cultural dynamics: Ferdinand de Saussure, Roland Barthes, Julia Kristeva, Jacques Derrida, Charles Sanders Peirce, Marcel danesi \& Paul Perron, etc]. Fakultas Ilmu Pengetahuan Budaya, Universitas Indonesia, 2008. pp. 19-26.

[9] Tinarbuko, Sumbo. "Semiotika Analisis Tanda Pada Karya Desain Komunikasi Visual [Semiotic Analysis of Signs in Visual Communication Design Work]." Nirmana 5.1 (2004). pp. 31-37. DOI: https://doi.org/10.9744/nirmana.5.1.

[10] Didik, Riyanto. Proses Batik. Batik Tulis, Batik Cap. [Batik Process. Handmade Batik, Stamp Batik]. (1997). p. 15.

[11] Rukmana, Rahmat. Mawar [Rose]. Yogyakarta: Kanisius (1995). p. 11.

[12] Balai, Pustaka. Kamus Bahasa Jawa (Bausastra Jawa) [Javanese Dictionary (Bausastra Jawa)]. Yogyakarta: Kanisius (2011). p. 233. 